\title{
Effect of social networking on academic achievement of dental students, Jazan University, Saudi Arabia
}

\author{
E. Halboub ', F. Othathi ${ }^{2}$, F. Mutawwam ${ }^{3}$, S. Madkhali ${ }^{2}$, D. Somaili ${ }^{3}$ and N. Alahmar ${ }^{4}$
}

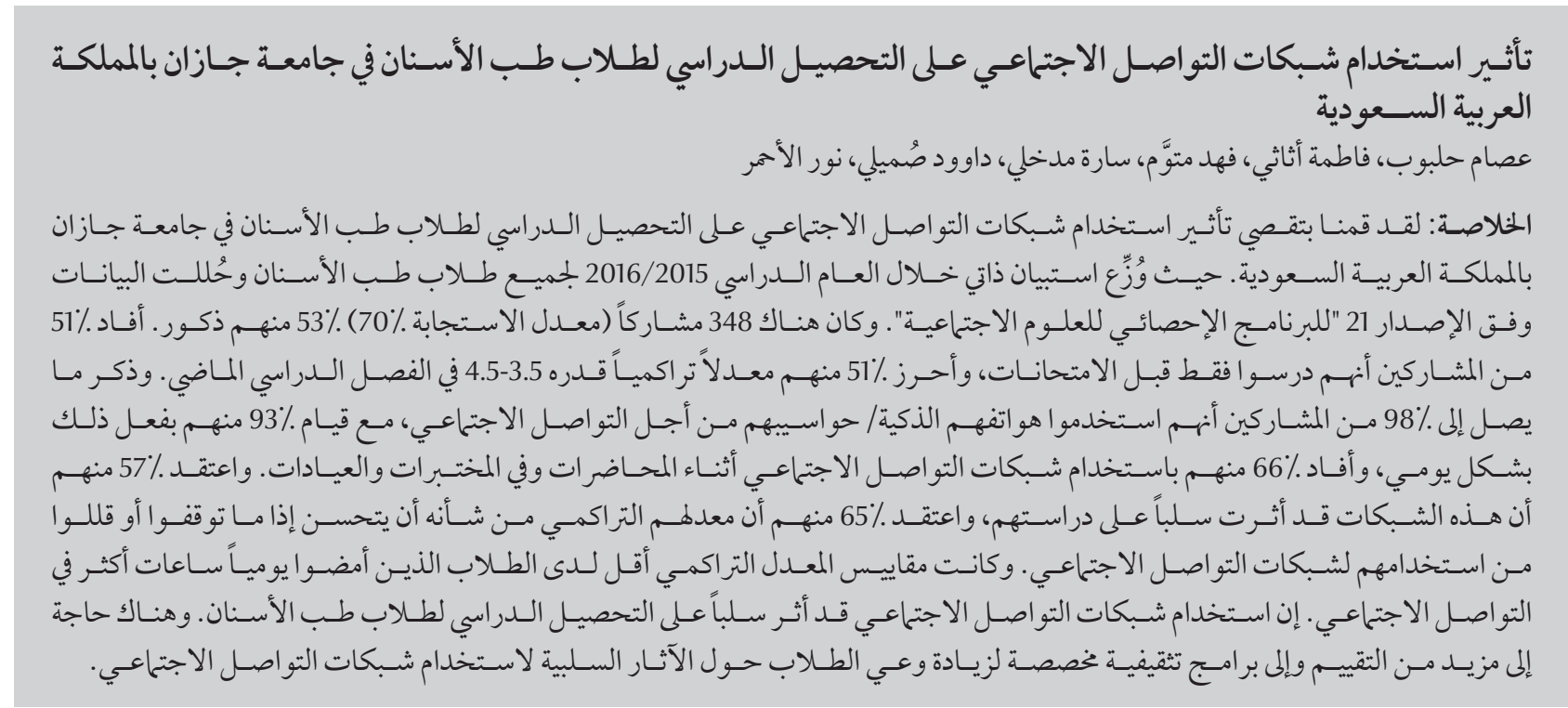

ABSTRACT We investigated the effect of social networking (SN) on academic achievement of dental students at Jazan University, Saudi Arabia. A self-administered questionnaire was distributed during the 2015/16 academic year to all dental students and data were analysed by SPSS version 21 . There were 348 participants (70\% response rate) and $53 \%$ were male. Fifty-one percent of participants reported that they studied just before examinations, and $51 \%$ scored $3.5-4.5$ Grade Point Average (GPA) in the last semester. Up to $98 \%$ of the participants reported using their smartphones/ computers for $\mathrm{SN}$, with $93 \%$ doing so on a daily basis, and $66 \%$ reported $\mathrm{SN}$ during lectures, laboratories and clinics. Fifty-seven percent thought that SN affected their study negatively, and 65\% thought that their GPA would improve if they stopped or reduced SN. Students who spent more hours each day on SN had lower GPA scores. SN negatively affected the academic achievement of dental students. Further evaluation and tailored educational programmes are needed to increase students' awareness about the negative effects of SN.

\section{Influence des réseaux sociaux sur la réussite universitaire des étudiants en médecine dentaire à l'université de Jazan, en Arabie saoudite}

RÉSUMÉ Nous avons étudié l'influence des réseaux sociaux sur la réussite universitaire des étudiants en médecine dentaire à I'Université de Jazan, en Arabie saoudite. Un questionnaire auto-administré a été distribué à tous les étudiants en médecine dentaire sur l'année universitaire 2015-2016, et les données ont été analysées à l'aide du logiciel SPSS, version 21. Au total, 348 étudiants ont participé (taux de réponse de $70 \%$ ), dont 53 \% d’hommes. Cinquante et un pour cent des participants ont rapporté qu'ils étudiaient juste avant les examens, et $51 \%$ ont obtenu une moyenne de 3,5-4,5 au dernier semestre. Jusqu'à $98 \%$ des participants ont rapporté qu'ils utilisaient leur smartphones/ordinateurs pour se connecter aux réseaux sociaux, dont $93 \%$ sur une base quotidienne, et $66 \%$ ont rapporté se connecter pendant les cours, en laboratoire et en clinique. Cinquante-sept pour cent pensaient que les réseaux sociaux avaient une influence négative sur leurs études, et $65 \%$ étaient d'avis que leur moyenne serait meilleure s'ils arrêtaient ou réduisaient leur utilisation des réseaux sociaux. Les étudiants qui passaient le plus de temps par jour sur les réseaux sociaux avaient des moyennes plus faibles. Les réseaux sociaux affectaient négativement la réussite universitaire des étudiants en médecine dentaire. De plus amples investigations et des programmes d'éducation adaptés sont requis pour sensibiliser les étudiants aux effets négatifs des réseaux sociaux. Jazan University, Jazan, Saudi Arabia. ${ }^{4} 4$ th level student, College of Dentistry, Jazan University, Jazan, Saudi Arabia.

Received: 31/03/16; accepted: 30/08/16 


\section{Introduction}

Increasingly popular and ubiquitous online social networks like Facebook, WhatsApp, Instagram and Twitter are changing the way we interact socially. Most of the users of these networks are aged 18-34 years, and life without social networking $(\mathrm{SN})$ is unthinkable to them. SN has become the medium for expression in every aspect of life, and it is now available on mobile phones, making it easy to communicate with relatives and friends (1). Hence, the impact and importance of $\mathrm{SN}$ are undeniable. Despite its advantages, SN can pose several hazards, particularly among users who are unmindful of these negative effects. It may be that most social network users do not realize the negative impact because they are already addicted $(2,3)$. In one study, 715 out of a total sample of 1000 medical students complained of mood swings in their daily life due to excessive use of Facebook (3).

Many studies have assessed the effect of $\mathrm{SN}$ on academic performance of university students $(1,3,4)$. Other studies have addressed, argued and/or emphasized the importance of studying this effect on dental students and educators (5-7). In one study, 30\% of medical students admitted that using Facebook had a negative effect on their academic performance, and 44\% reported that they surfed Facebook during their study hours. Around 27\% of these students reported that their Grade Point Average (GPA) had decreased compared to $9 \%$ who reported an increase in their GPA (3). In Saudi Arabia, SN usage is apparently huge. Al Shawwa et al. (4) evaluated the factors that might have affected the academic performance of a sample of medical students in Saudi Arabia. They included a question on time spent on $\mathrm{SN}$ and reported a negative effect on academic performance, although it was not significant.
The aim of the present study was to explore the multifaceted effects of surfing social networks (Facebook, WhatsApp, Instagram and Twitter) on the academic achievement of dental students at Jazan University, Saudi Arabia.

\section{Methods}

This cross-sectional study targeted students at the College of Dentistry, Jazan University during the first semester of the 2015/16 academic year. All participants were full-time students in the second to sixth levels of the dental programme, and voluntarily agreed to participate in the study. There were 2 exclusion criteria: unwillingness to participate in the study, and absence from the previous semester examinations. The study was approved by the Institutional Review Board of the College of Dentistry, Jazan University.

A self-administered questionnaire was designed for this study. It was tested for content validity by 3 of the College staff. It was piloted with a sample of 15 male and 15 female dental students to test readability and understandability. Based on their comments, the questionnaire was appropriately modified. The questionnaire comprised 19 items covering: students' achievement (GPA, which included theoretical, practical and clinical achievement) in the previous semester; failing in $\geq 1$ subject in the previous semester; time spent (hours/day and days/week) in revising the study topics; gender and age; level of study; owning a smartphone and/or personal computer; utilizing (surfing) social networks/programmes (Facebook, WhatsApp, Instagram and Twitter); and time spent, hours/day and days/week, surfing these networks.

A covering letter accompanied the questionnaire introducing the investigator, explaining the study objectives and encouraging students' participation. At the same time, it assured anonymity for all participants in addition to data confidentiality. Two male and 3 female dental students distributed the questionnaires to eligible male and female students, respectively. They explained the study aims, voluntary participation and confidentiality of participants' data. Students were given adequate time to complete the questionnaire.

Completed questionnaires were input into SPSS version 21 (IBM Corp., Armonk, NY, USA). Data were presented as frequencies and percentages. GPA was dichotomized as lower, $<4.5$ and higher, $\geq 4.5$. Determinants of these two categories were identified using a multiple logistic regression model. Determinants of "Days assigned for athome study", which had an inherited numerical characteristic, were identified using a multiple linear regression model. $P<0.05$ was considered significant.

\section{Results}

The demographic and academic characteristics of the study sample are presented in Table 1. There were 348 participants (70\% response rate): 185 (53.2\%) were males and 297 (85.8\%) were aged 20-25 years. One hundred and seventy-eight (51.7\%) participants reported that they studied on the day before the examination, and a similar number scored 3.5-4.5 GPA in the previous semester.

Table 2 reports the participants' responses regarding using $\mathrm{SN}$. All participants had smartphones/personal computers, and 343 (98.8\%) reported using them for $\mathrm{SN} ; 322$ (93.3\%) on a daily basis and nearly $53 \%$ did so for 4-6 hours and more daily. Two hundred and twenty-seven (65.8\%) participants reported SN during lectures/laboratories/clinics always (10,2.9\%), mostly $(27,7.8 \%)$ or usually $(190,55.1 \%)$. One hundred and ninety-six (56.6\%) believed SN affected their study negatively, and 224 (64.7\%) thought that their GPA could have been improved if they had stopped or reduced $\mathrm{SN}$. 


\begin{tabular}{|c|c|c|}
\hline Characteristics & $n$ & $\%$ \\
\hline \multicolumn{3}{|l|}{ Sex } \\
\hline Male & 185 & 53.2 \\
\hline Female & 163 & 46.8 \\
\hline \multicolumn{3}{|l|}{ Age group $(n=346)$} \\
\hline$<20$ years & 46 & 13.3 \\
\hline 20-25 years & 297 & 85.8 \\
\hline$>25$ years & 3 & 0.9 \\
\hline \multicolumn{3}{|c|}{ College level (year) of students } \\
\hline Second & 89 & 25.6 \\
\hline Third & 89 & 25.6 \\
\hline Fourth & 82 & 23.6 \\
\hline Fifth & 40 & 11.5 \\
\hline Sixth & 46 & 13.8 \\
\hline \multicolumn{3}{|c|}{ GPA in previous semester $(n=344)$} \\
\hline$<2.5$ & 3 & 0.9 \\
\hline $2.5-3.5$ & 51 & 14.8 \\
\hline$>3.5$ to 4.5 & 178 & 51.7 \\
\hline$>4.5$ & 112 & 32.6 \\
\hline \multicolumn{3}{|c|}{ Did you fail any subjects last semester? } \\
\hline Yes & 17 & 4.9 \\
\hline No & 331 & 95.1 \\
\hline \multicolumn{3}{|c|}{ Which days did you assign for at-home study? $(n=345)$} \\
\hline All days of the week & 20 & 5.7 \\
\hline$>3$ days per week & 47 & 13.6 \\
\hline$<3$ days per week & 100 & 29 \\
\hline Day before examination & 178 & 51.6 \\
\hline \multicolumn{3}{|c|}{ How many hours did you spend for study on the days you assigned? $(n=344)$} \\
\hline$<4$ & 118 & 34.3 \\
\hline $4-6$ & 107 & 31.1 \\
\hline$>6$ to 8 & 56 & 16.3 \\
\hline$>8$ & 63 & 18.3 \\
\hline
\end{tabular}

$a=348$ unless otherwise indicated . GPA = Grade Point Average.

Male gender, SN during lectures/ laboratories/clinics, and assigning more hours/day for SN were associated with lower GPA scores (Table 3, Figure 1). In contrast, lower college level of students and assigning more days/week for study were associated with higher GPA.

The number of days devoted to study was negatively affected by an increase in the number of days allocated to SN $(P=0.002)$, using smartphones/computers $(P<0.001)$, college level of students $(P=0.001)$, SN performance. Lack of awareness of time management might lead to poor academic performance. This is likened to a state of addiction $(2,3)$. In the current study, $56.6 \%$ of the participants believed that $\mathrm{SN}$ had a negative effect on their study, and $64.7 \%$ claimed that their academic performance could be improved if they stopped SN. However, $57.2 \%$ of them admitted that they could not stop $\mathrm{SN}$ even during the examination period.

In the current study, all participants reported that they had smartphones/ laptops. This figure is similar to that reported for dental students in New Zealand (98\%) (8) but higher than that reported by dental students in England (55\%) (9). Technology should enhance the educational process, if used properly. In developed countries, for example, researchers evaluated the extent to which such technologies are utilized, and/or how they can enhance learning (8-13). In addition, it has been suggested that $\mathrm{SN}$ can be a valuable learning source for dental practitioners and their patients (6).

Although most of the participants in our study claimed to use their smartphones/laptops for reading study references/materials, this appears to have been haphazard (not systematic) and unsupervised. Indeed, this factor had no direct effect on GPA, although it was associated positively with the number of days that students assigned for athome study. Two factors related to using smartphones/laptops for $\mathrm{SN}$ were associated with lower GPA: hours/day assigned for $\mathrm{SN}$, and surfing during lectures. Similar results, although to a lesser extent, were reported previously by $\mathrm{Al}$ Shawwa et al. (4) in Saudi Arabia and Farooqi et al. (3) in Pakistan.

In the current study, participants who assigned more days for at-home study had higher GPA scores. However, the number of days assigned for at-home study was negatively affected by many factors related to using smartphones/laptops for SN. This reflects the extent to which students abuse these 


\begin{tabular}{|c|c|c|}
\hline Items & $n$ & $\%$ \\
\hline \multicolumn{3}{|c|}{ Do you have/use a smart phone/computer currently? $(n=348)$} \\
\hline Yes & 348 & 100 \\
\hline No & 0 & 0 \\
\hline \multicolumn{3}{|c|}{ Do you use your smart phone/computer for surfing social networks? $(n=347)$} \\
\hline Yes & 343 & 98.8 \\
\hline No & 4 & 1.1 \\
\hline \multicolumn{3}{|c|}{ How many days/week did you surf these social network sites/programmes? $(n=345)$} \\
\hline All & 322 & 93.3 \\
\hline$>3$ & 14 & 4.1 \\
\hline$<3$ & 9 & 2.6 \\
\hline \multicolumn{3}{|c|}{ How many hours did you spend on surfing these social network sites/programmes? $(n=344)$} \\
\hline$<2$ & 54 & 15.7 \\
\hline $2-4$ & 108 & 31.4 \\
\hline$>4$ to 6 & 109 & 31.7 \\
\hline$>6$ & 73 & 21.2 \\
\hline \multicolumn{3}{|c|}{ Have you ever been absent in a lecture/laboratory/clinical session because of SN? $(n=346)$} \\
\hline Yes & 21 & 6.1 \\
\hline No & 325 & 93.9 \\
\hline \multicolumn{3}{|c|}{ Do you surf these social network sites/programmes during lectures/laboratories/clinical sessions? (n=345) } \\
\hline always & 10 & 2.9 \\
\hline Mostly & 27 & 7.8 \\
\hline Usually & 190 & 55.1 \\
\hline No & 118 & 34.2 \\
\hline \multicolumn{3}{|c|}{ Do you think that surfing these network sites/programmes might negatively affect your academic performance? $(n=346)$} \\
\hline Yes & 196 & 56.6 \\
\hline No & 150 & 43.4 \\
\hline \multicolumn{3}{|c|}{$\begin{array}{l}\text { Do you think that your academic performance will be improved if you stop completely, or at least, reduce your surfing of thes } \\
\text { social network sites/programmes? }(n=346)\end{array}$} \\
\hline Yes & 224 & 64.7 \\
\hline No & 122 & 35.3 \\
\hline \multicolumn{3}{|c|}{ Do you think that it is possible to utilize these social network sites/programmes to improve academic performance? $(n=346$} \\
\hline Yes & 335 & 96.8 \\
\hline No & 11 & 3.2 \\
\hline \multicolumn{3}{|c|}{$\begin{array}{l}\text { Do you think that you can stop surfing these social network sites/programmes completely during the examination period? } \\
(n=346)\end{array}$} \\
\hline Yes & 148 & 42.8 \\
\hline No & 198 & 57.2 \\
\hline \multicolumn{3}{|c|}{ Do you use your smart phone/computer to read or surf study references? $(n=346)$} \\
\hline Always & 139 & 40.2 \\
\hline Mostly & 92 & 26.6 \\
\hline Usually & 112 & 32.2 \\
\hline No & 3 & 0.9 \\
\hline
\end{tabular}

${ }^{a}$ WhatsApp, Facebook, Instagram and Twitter.

technologies and how little they are aware of the damage caused. Whether this behaviour is an addiction should be confirmed by psychosocial studies. College faculties need to pay attention to this overall negative impact and perhaps do something about it.

Apart from the effects of SN-related factors, several other factors affected GPA. Higher GPAs were associated with lower college levels of study, female gender and assigning more days for at-home study. The role of the last factor was confirmed in the study of $\mathrm{Al}$ Shawwa et al. (4). However, it is not 


\begin{tabular}{|c|c|c|c|}
\hline Determinants & $\begin{array}{l}\text { Adjusted odds } \\
\text { ratio }\end{array}$ & $\begin{array}{l}\text { 95\% confidence } \\
\text { interval }\end{array}$ & $P$ value \\
\hline \multicolumn{4}{|l|}{ Level of study } \\
\hline 2nd & \multicolumn{3}{|c|}{ Reference } \\
\hline $3 r d$ & 0.66 & $0.33-1.3$ & 0.233 \\
\hline 4 th & 0.15 & $0.07-0.33$ & $<0.001$ \\
\hline 5 th & 0.16 & $0.06-0.46$ & 0.001 \\
\hline 6th & 0.15 & $0.05-0.46$ & 0.001 \\
\hline \multicolumn{4}{|l|}{ Days assigned for study } \\
\hline Day before examination & \multicolumn{3}{|c|}{ Reference } \\
\hline Daily & 2.25 & $0.71-7.12$ & 0.172 \\
\hline$\geq 3$ days/week & 2.91 & $1.29-6.25$ & 0.011 \\
\hline$<3$ days/week & 2.22 & $1.18-4.18$ & 0.013 \\
\hline \multicolumn{4}{|c|}{ Hours/day assigned for social networking } \\
\hline$<2$ & \multicolumn{3}{|c|}{ Reference } \\
\hline $2-4$ & 0.88 & $0.4-1.94$ & 0.743 \\
\hline $4-6$ & 0.34 & $0.15-0.79$ & 0.012 \\
\hline$>6$ & 0.55 & $0.23-1.42$ & 0.178 \\
\hline \multicolumn{4}{|c|}{ Surfing social networks during lectures/laboratories/clinics } \\
\hline No & \multicolumn{3}{|l|}{ Reference } \\
\hline Yes & 0.48 & $0.27-0.85$ & 0.011 \\
\hline \multicolumn{4}{|l|}{ Gender } \\
\hline Male & \multicolumn{3}{|c|}{ Reference } \\
\hline Female & 1.75 & $1.01-3.03$ & 0.045 \\
\hline
\end{tabular}

${ }^{a}$ Multiple logistic regression. Dependent variable (Grade Point Average) was dichotomized: $<4.5$ and $\geq 4.5$. Adjusting was done for all variables included in Tables 1 and 2 except "Did you fail any subjects last semester". Cox and Snell pseudo $R 2=0.238$.

clear why academic performance decreases with higher levels of study. Is it due to the difficulty of the courses, clinical training at higher levels, or reduced interest of students at higher levels? In fact, we found that students at higher levels were more frequently engaged in SN during lectures (data not shown).
In light of the findings of the current study, it is difficult to explain why female students outperform their male peers. The bivariate analyses did not reveal significant differences related to any of the included factors (data not shown). In a study of Jordanian dental students, women achieved higher GPAs in theoretical courses, whereas in practical courses, the differences were not so clear cut (14).

Academic performance is a complex issue in which many factors interact $(4,15-17)$. In addition to the cognitive factors (e.g., GPA in high school, and admission examination and interview), many non-cognitive factors related to student personality ought to

\begin{tabular}{lcccc}
\hline Table 4 Determinants ${ }^{\mathrm{a}}$ of number of days assigned for at-home study & & & \\
\hline Determinants & B value & $\begin{array}{c}\mathbf{9 5 \%} \\
\text { confidence } \\
\text { interval }\end{array}$ & $\boldsymbol{R}^{\mathbf{2}}$ & $\boldsymbol{P}^{\text {value }}$ \\
Days assigned for social networking & -0.41 & $-0.67,-0.16$ & 0.047 & 0.002 \\
Using smartphones/computer for social networking & -1.88 & $-2.83,-0.92$ & 0.089 & $<0.001$ \\
Level of study & -0.11 & $-0.18,-0.04$ & 0.12 & 0.001 \\
Surfing social networks during lectures/laboratories/clinics & -0.23 & $-0.43,-0.03$ & 0.131 & 0.023 \\
Using smartphone/computer for reading references & 0.12 & $0.01,0.22$ & 0.141 & 0.029 \\
Hours/day assigned for social networking & -0.1 & $-0.19,-0.01$ & 0.149 & 0.037 \\
\hline
\end{tabular}

${ }^{a}$ Stepwise multiple linear regression. 


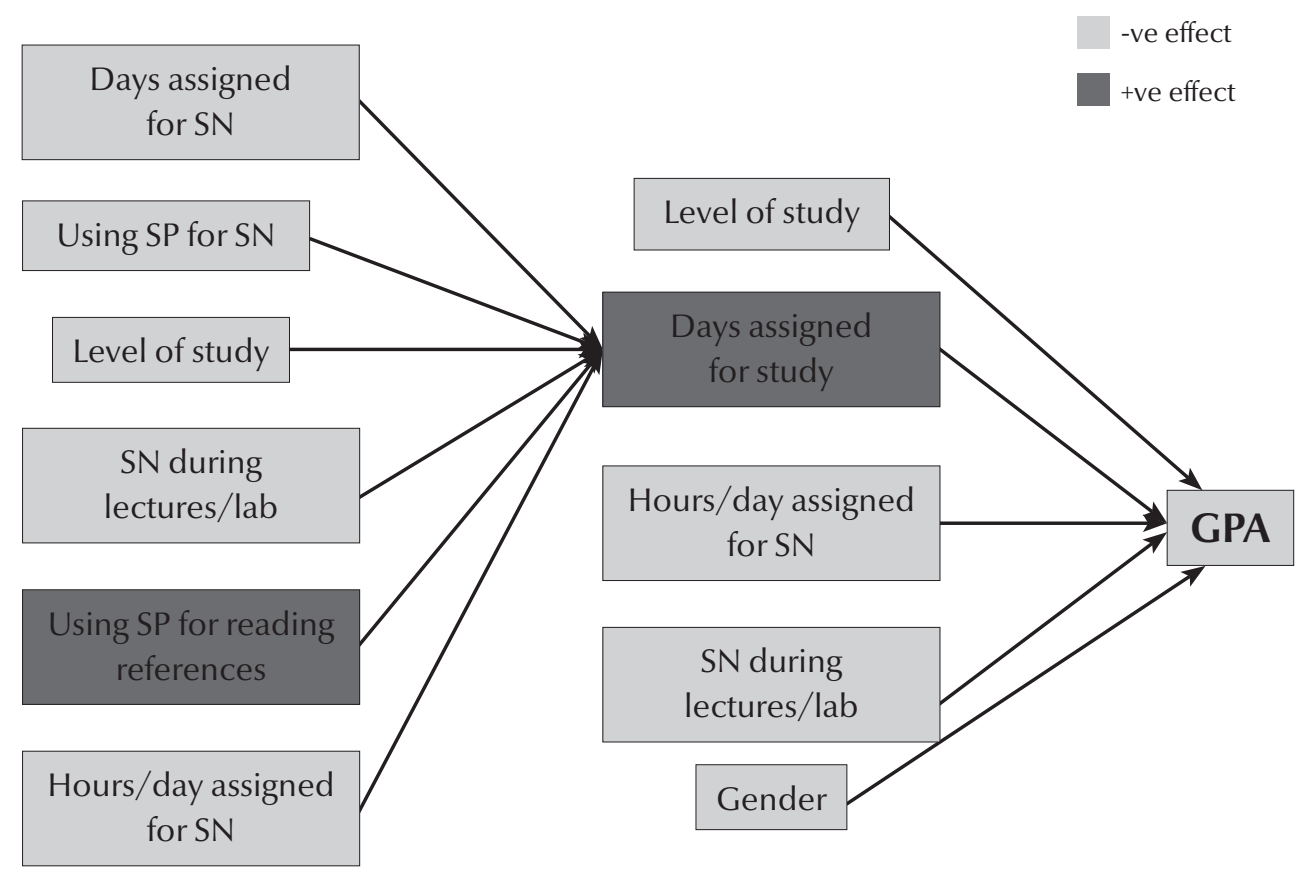

Figure 1 Illustration of effects of different factors on academic performance of dental students at Jazan University. The right column presents the factors that have a direct effect on GPA, while the left column represents the factors that influence the days/week assigned by students for at-home study. GPA = Grade Point Average; SN = social networking; SP = smartphone.

be considered, such as: locus of control, self-efficacy, self-directed learning and interpersonal communication (17).

Regarding dental practice and education, the General Dental Council in the United Kingdom of Great Britain and Northern Ireland issued guidelines on the use of social media that suggest $\mathrm{SN}$ has the potential to expose dental professionals to a variety of breaches of professional conduct (6). In addition, it has been argued that unprofessional use or misuse of $\mathrm{SN}$ can erode the social contract and/or the contract of confidentiality between the dental practitioners/students and their community/patients. Hence, a rigorous research agenda on this topic is mandatory $(5-7)$.

The study had some limitations. In view of being cross-sectional, a sound conclusion cannot be drawn from the results. Most of the participants' responses relied on recall and/or guessing, and both might have been inaccurate. A longitudinal design in which data are collected immediately upon enacting a given behaviour would overcome this limitation. Another limitation was restricting our sample to dental students; recruiting students from other colleges might reveal in-depth knowledge on the real effects of $\mathrm{SN}$.

\section{Conclusion}

SN appears to affect dental students' academic achievement negatively. The findings of the current and other studies should be used as basis for addressing this problem. College authorities should urgently design awareness programmes for dental students to reduce the negative effects of $\mathrm{SN}$.

\section{Funding: None.}

Competing interests: None declared.

\section{References}

1. Suhail K, Bargees Z. Effects of excessive Internet use on undergraduate students in Pakistan. Cyberpsychol Behav. 2006 Jun;9(3):297-307.

2. Walsh JL, Fielder RL, Carey KB, Carey MP. Female college students' media use and academic outcomes: results from a longitudinal cohort study. Emerg Adulthood. 2013 Sep 1;1(3):219-32.

3. Farooqi $\mathrm{H}$, Patel $\mathrm{H}$, Aslam HM, Ansari IQ, Khan M, Iqbal N, et al. Effect of Facebook on the life of Medical University students. Int Arch Med. 2013 Oct 17;6(1):40.
4. Al Shawwa L, Abulaban AA, Abulaban AA, Merdad A, Baghlaf $S$, Algethami $A$, et al. Factors potentially influencing academic performance among medical students. Adv Med Educ Pract. 2015 Jan 29;6:65-75.

5. Arnett MR, Loewen JM, Romito LM. Use of social media by dental educators. J Dent Educ. 2013 Nov;77(11):1402-12.

6. Neville P, Waylen A. Social media and dentistry: some reflections on e-professionalism. Br DentJ. 2015 Apr 24;218(8):475-8. 
7. Oakley M, Spallek H. Social media in dental education: a call for research and action. J Dent Educ. 2012 Mar;76(3):279-87.

8. Cox S, Pollock D, Rountree J, Murray C. Use of information and communication technology amongst New Zealand dental students. EurJ Dent Educ. 2016 Aug;20(3):135-41.

9. Khatoon B, Hill KB, Walmsley AD. Dental students' uptake of mobile technologies. Br Dent J. 2014 Jun;216(12):669-73.

10. Henry RK, Molnar AL. Examination of social networking professionalism among dental and dental hygiene students. J Dent Educ. 2013 Nov;77(11):1425-30.

11. Khatoon B, Hill KB, Walmsley AD. Instant messaging in dental education. J Dent Educ. 2015 Dec;79(12):1471-8.

12. Smith W, Bedayse S, Lalwah SL, Paryag A. Computer literacy and attitudes of dental students and staff at the University of the West Indies Dental School. Eur J Dent Educ. 2009 Aug;13(3):179-83.

13. Stein CD, Eisenberg ES, O'Donnell JA, Spallek H. What dental educators need to understand about emerging technologies to incorporate them effectively into the educational process. J Dent Educ. 2014 Apr;78(4):520-9.

14. Sawair FA, Baqain ZH, Al-Omari IKh, Wahab FK, Rajab LD. Effect of gender on performance of undergraduate dental students at the University of Jordan, Amman. J Dent Educ. 2009 Nov;73(11):1313-9.

15. Jedrychowski J, Lindemann R. Comparing standardized measures of diligence and achievement with dental student academic performance. J Dent Educ. 2005 Apr;69(4):434-9.

16. Stacey DG, Whittaker JM. Predicting academic performance and clinical competency for international dental students: seeking the most efficient and effective measures. J Dent Educ. 2005 Feb;69(2):270-80.

17. Ihm JJ, Lee G, Kim KK, Jang KT, Jin BH. Who succeeds at dental school? Factors predicting students' academic performance in a dental school in republic of Korea. J Dent Educ. 2013 Dec;77(12):1616-23. 